\title{
(THIS OFTEN) SYMPATHETIC COLLABORATION: ANTHROPOLOGISTS, ACADEMIC FREEDOM AND GOVERNMENT,
}

I $9^{2} 7^{-1} 95^{2}$

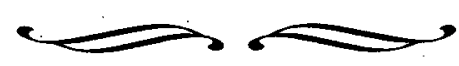

\begin{abstract}
A
ustralian anthropologists such as Ronald Berndt were keen to present themselves as being on the side of the underdogs, in Berndt's words, by representing 'the virtually inarticulate Aborigines'. This implies not only a traditional mediating role but also an advocacy role for anthropologists. At first glance, for those familiar with the history of Australian anthropology, this seems plausible. However, there is little to show of the advocacy Berndt suggests. J.A.

Barnes observed, in 1988 , that improvements in the position of Aborigines were not due to anthropological pressure. ${ }^{2}$ Also, anthropologists rarely made public comments on the treatment of Indigenous peoples in Australia's then colonial territories of Papua, New Guinea, and Nauru. ${ }^{3}$ Nevertheless there is a view, often expressed by anthropologists, that they were (and are) distrusted (if not disliked) by government, as if there was a natural antinomy between administrative interests and academic interests.

Sometimes the colonial administrator was anxious about the motives of the
\end{abstract}

anthropologist and concerned that the anthropologist would bring some aspect of colonial administration to public notice. ${ }^{4}$ However, an examination of anthropological texts does not reveal this antinomy between anthropologists and government. Secondly, the view that government distrusted anthropologists is a modern invention that masks the relationship anthropologists need(ed) to develop with government and its agents if they are to conduct and, more importantly, continue their research. ${ }^{5}$

Such an appraisal, of course, runs the risk of appearing to elide the ambiguous situation in which anthropologists were often situated. On the one hand, anthropologists were dependent on government(s) for resources and for access to the people studied. On the other hand, anthropologists were disposed towards a sympathetic presentation of a native point of view and social structure. ${ }^{6}$ Such a view set up anthropology as a discipline which spoke for native peoples. The British anthropologist Reo Fortune, for instance, stated that the anthropologist 
was the 'friend of the native' who did not 'betray' them to the colonial administration. ${ }^{7}$ He observed that the anthropologist was in a somewhat delicate position regarding native society. His conclusions,

may differ so radically from the established practice of his hosts and befrienders of Mission and Grovernment in dealing with that society that he knows beforehand that they will be received with a conservatism that may amount to rejection. This would be bad enough in itself if it were all ... The anthropologist makes public information of facts which native reticence would else have kept private and unknown to Mission and Administration. $^{8}$

It is this position-advocacy and speaking for native peoples - that created the ambiguities and ambivalences found in anthropological writing and public comment. Such insider knowledge inadvertently produces a moral dimension to the positioning of anthropologists which is seemingly denied others who worked in native affairs. This will emerge in the following discussion.

The relationship between anthropologists and (colonial) government enhanced a tendency within anthropological scholarly writing to present a social reality that appears as if native peoples were insulated from the changes brought by settler, mission, and government. 9

Anthropologists tended to express the contemporary social reality elsewhere: in private correspondence, diaries, and confidential reports. ${ }^{10}$ Matters to do with the effects of dispossessory occupation was, in the Australian context, reflected in a contempt for ethnography based on

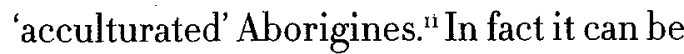
argued that the ethnography produced in the three decades after 1926 when the Chair of Anthropology at the University of Sydney was established hardly deals with culture contact or social change. This paper, however, is not concerned with an analysis of private and public discourses but the broader question of academic and civil freedom, of how the academy deals with public dissent that threatens the viability of a research program or perhaps the institution itself. ${ }^{\text {I2 }}$

Issues of academic and civil freedom are not solely the domain of Australian anthropology. Funding bodies often reflect, albeit covertly, the national interest. There are a number of American examples that are relevant. During and after the Pacific War, the American military employed anthropologists to undertake research in Micronesia: Glen Alcalay found it 'troubling that anthropologists ... did not raise more of an objection concerning their role in aiding the colonial project in Micronesia'.3 Glenn Petersen, in a paper delivered to the American Association of Anthropologists, articulated similar views. ${ }^{14}$ Project Camelot, initiated in 1964 , likewise presented ethical and moral dilemmas for anthropologists. Camelot was a project sponsored by the United States Department of Defence to study areas of insurgency and potential revolution in the 
Third World, and to ascertain ways to offset such developments. Kathleen Gough, one of the main critics of Camelot, argued that anthropology had served government, empire, and capitalism, a criticism frequently levelled at the discipline..$^{55}$

Australian academics, in the period under discussion, were closely associated with government and were generally uncritical of government Aboriginal policy and practice.$^{16}$ International criticism over the treatment of Aborigines enhanced the need for government and the academy together to maintain silence, or restore silence. I have previously examined why Australian academics were so supine when it came to public criticism of the treatment of Aborigines by examining the treatment of Ralph Piddington by the Australian National Research Council (ANRC) for his public criticism of the treatment and conditions of Aborigines in north-west Western Australia. ${ }^{17} \mathrm{My}$ conclusion was that the overriding explanation was the close association between government and academia. This reluctance is partly explained by their dependence upon governments; both state and federal, for research funds, and in the case of the ANRC obtaining permission for research workers to work in remote parts of Australia, particularly north-west Australia, and its colonial territories.

This historical relationship has created ethical difficulties for anthropologists, funding bodies, academic institutions, and government. There was (and still is) something inherently tricky about being an anthropologist. To maintain and sustain the discipline, anthropologists needed to assess their political circumstances, obligations, opportunities, and risks.

The ANRC was formed in rgrg to be Australia's primary link with the International Research Council and other international scientific institutions. Its membership, limited to leading scientists, made it an influential body with government. It was a key body in promoting the formation of a chair of anthropology which it did through the Pan Pacific Congress in ig23, and in representations to government. The Congress was a significant moment in the formation of a chair. Elkin argued that the initial success arose from the standing of the Pacific Science Congress, the status of the [ANRC], and the calibre of the individual scientists concerned.' ${ }^{\mathrm{r}} 8$ Nevertheless, for Elkin the Australian anatomist and diffusionist Grafton Elliot Smith was 'the key figure' in the establishment of the chair. ${ }^{19}$ It was he who was 'consulted by the Rockefeller Foundation about ... a Chair in the University of Sydney and about the field work which was proposed in connection with it.' ${ }^{20}$

The Rockefeller Foundation was interested in having discussions with the commonwealth government and scientists with respect to the possibility of carrying on investigations of the Australian 
Aborigines'; in the words of the Board of Trustees of the Foundation:

Our position is that if the Australian Universities either individually or collectively have or wish to develop plans for studies of aboriginal peoples, and if they need financial assistance in carrying out these plans and care to approach the Rockefeller Foundation with respect to such assistance, we are prepared to sympathetically consider such proposals .... As to the scope of the studies, this will depend upon the resources, the personnel and the plans of the Australian Universities ... The types of studies ... might include not only such items as are regularly thought of as falling under the general subject of anthropology, but also those which would include what might be called immunology and comparative physiology on the one hand and ethnology, social customs, and organisation on the other. ${ }^{21}$

The Foundation agreed to make appropriations to the ANRC for anthropological research for an amount not exceeding $\$ \mathrm{US}_{25}$ o, oo a a year for five years, 'the amount contributed by the Foundation to be determined by the amount contributed for similar purposes from other sources'. ${ }^{22}$ There were no funds forthcoming from local or international funding bodies other than the commonwealth and state governments.

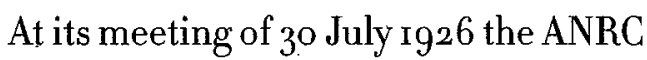
accepted the offer from the Rockefeller Foundation, and appointed an Advisory Committee on Anthropology which would make recommendations for anthropological research. The organization of field research would be in the hands of the Professor of Anthropology at the University of Sydney and the committee, which included representatives of the states, commonwealth and the ANRC. ${ }^{23}$ With the exception of the initial meetings, the committee met in Sydney; this had the effect of increasing the power of the chair and those Sydney-based members who attended. By the end of the 1920 s the chair was increasingly influential in the choice of researcher and field site: ${ }^{24}$ The geographic scope of research under the auspices of the committee included Australia, its territories, and Melanesia. ${ }^{25}$ John Mulvaney argues, rightly, that Ralph Piddington's treatment by the ANRC was possibly the 'first of several blatant denials of academic (and civil) freedom to anthropologists. Such cases involved a government instrumentality acting in concert with the often sympathetic collaboration of the relevant timid or politicised academic establishment' ${ }^{26}$ It is this 'often sympathetic collaboration' with government that I want to examine in this paper by focusing on the treatment of Ralph Piddington and Paul Kirchhoff by the ANRC. ${ }^{27}$ Secondly, I want briefly to discuss a postwar example-Peter Worsley. Here the Australian government refused Worsley entry to Papua New Guinea because it believed that Worsley's presence would be detrimental to the good order of government. What characterizes the actions of the academic 
hierarchy in these cases is its unquestioning acceptance of the situation as stated by the relevant government instrumentality. Piddington, Kirchhoff, and Worsley were victims of the academy's timidity and complicity, and its sympathetic collaboration with government to stifle academic and civil freedom.

Piddington was not the only anthropologist to draw attention to the plight of Aborigines, nor were Piddington, Kirchhoff, and Worsley the only anthropologists to be victimized or hindered by the academic hierarchy because of their publicly expressed views and opinions, or membership of the communist party. Donald Thomson, a Melbourne biologist and anthropologist, by his criticism of missionaries in Cape York Peninsula, drew the disapproval of the ANRC, and later A.P. Elkin, professor of anthropology from I934 until 1956 . Thomson did not, after his initial funding in $\mathrm{I}_{22} 8$, receive any further funding from the ANRG..$^{28}$ When Donald Thomson wrote a number of articles for the Melbourne Herald (December I946) and the Sydney Morning Herald (January I947) critical of the treatment of Aborigines in the Northern Territory, Elkin came to the defence of the government and accused Thomson of exaggeration. Elkin, through his association with misssion bodies, encouraged them to write to the editors of these papers criticizing and questioning Thomson's knowledge. ${ }^{29}$
Between August r944 and March 1946 Ronald and Catherine Berndt undertook a survey of the conditions and welfare of Aboriginal pastoral workers employed on Vestey's pastoral stations in the Northern Territory. Appalled and outraged by what they saw, these two young anthropologists kept both E.W.P. Chinnery, Director of Natives Affairs in the Northern Territory and Commonwealth Advisor on Aborigines, and Elkin informed of not only what they saw but how they proposed the situation could be improved. At the end of 1946 they produced a report with the expectation that it would be published. Elkin, however, advised them against publication unless they removed the names of the pastoral company and the pastoral stations. He maintained this position until his death in 1979 ; it was not until 1987 that a version of the report was published $3^{\circ}$

Olive Pink publicly drew attention to the 'white man's misuse of the Aboriginal population', in her address to the ANZAAS conference of $1935^{31}$ She argued that the 'men who knew most' about conditions in central Australia, the anthropologists, missionaries, and administrators, worked together to "camouflage the true, deplorable, state of affairs there' ${ }^{\prime 2}$ and 'kept... silent about the true situation of the Aborigines'.33 As a result she made herself unpopular with Elkin and the ANRC. She returned to the field but her work was marginalized and her funding ceased after $193^{6.34}$ 
Olive Pink was in her mid-forties when she accepted an invitation from Raymond Firth, acting Professor of Anthropology at the University of Sydney, to enrol as a nonmatriculated student in anthropology.35. Pink had returned from a trip to central Australia during which she had seen firsthand some of the appalling abuses of Aborigines. This trip had increased her interest in anthropology and 'suggested to her that the needs of and interests of Aboriginals might be advanced if anthropologists were able to work among them' ${ }^{3}$ She was moved enough to resign from her government position and pursue anthropology full-time. Pink, from this time, was an advocate for Aboriginal people and she fought for the improvement of their conditions and treatment throughout her life. She was critical of anthropologists, missionaries, and government officials who in turn created difficulties for Pink. Marcus argues, convincingly, that Pink's marginalization was due primarily to the contrary position she took with regard to knowledges produced by male anthropologists: 'Pink's interests in the real state of Aboriginal Australians, in their economic and sexual exploitation, in their poverty, health, and deaths, ran counter to the notions of pure science being purveyed in her university seminars' ${ }^{37}$ Yet she was unable to further her anthropological studies because she lacked formal qualifications and this was used against her when she continued to challenge the 'true situation' in central
Australia. ${ }^{8}$ Cheater contends that Pink discovered that an emotional attachment to the Aborigines could not be combined with the scientific study of the Aborigines. When the "men of science" forced her to choose between academic recognition and what she saw as a betrayal of a confidence [to her Aboriginal informants], Olive rejected anthropology'.

In $193^{8}$ when she decided to withdraw from anthropology Elkin supported depositing her records of Walbiri secret life for safe-custody. Elkin informed the ANRC that her reason for 'desiring to do this is that she will not break any faith with the Aborigines who entrusted the information to her'. He did not think the discipline would lose anything because 'the matter stored consists mainly of linguistic records of myths and descriptions of certain rites, but mainly the former, and such tabulation is not Miss Pink's strong point. The general principles of the secret life as far as she was able to obtain have been written up by her in her report which she presented to me'.39

From then on Pink no longer worked as an anthropologist, nor did she publish any of her earlier research. Pink herself offered an explanation for not publishing her research:

anthropology in the hands of administrators, patrol officers, cadets and missionaries, is being used to dominate and enslave [Aborigines] further ... to turn them from proudly independent landowners into regimented serfs ... or encouraged derelicts 
and diseased 'hanger's on'... on Mission reserves, or on camps (useful as brothels) near white mining camps and settlements and at station homesteads. $4^{\circ}$

\section{I. 'IN VIEW OF THE OBVIOUS ANIMUS'}

Ralph Piddington was an anthropological researcher with the ANRC at La Grange Bay, north-west Western Australia in $193^{\circ}$ and I931. Soon after his return to Sydney, in January 1932, he was interviewed by a Sydney weekly, The World. In the interview, entitled 'Aborigines On Cattle Stations Are In Slavery', he cited specific cases of gross racial discrimination and violence. The World commented that 'his observations reveal slavery of natives, trafficking in lubras, and the murdering and flogging of aborigines by white mensimilarly disclosed by Francis Birtles in his statements to The World regarding conditions in the Northern Territory.' The response from the department of Home Affairs that Birtles's allegations of illtreatment were not 'sufficiently definite to warrant official inquiries show that the Department knows nothing of affairs in the northern parts of the Commonwealth', said Mr Piddington. 'In fact, any inquiry would be fruitless unless it was conducted by persons who understand the native mentality and are known and trusted by the natives. It is difficult to obtain definite evidence because so many white men are implicated and the natives are suspicious of anyone whom they do not know, nor have white men in general given them any reason for confidence. ${ }^{\text {'4r }}$ He added that abuses at La Grange Bay were typical of the state of affairs in Western Australia.

Piddington had previously raised these matters with A.O. Neville, Chief Protector of Aborigines in Western Australia, as well as bringing to his notice the provision of alcohol to Aborigines and the misappropriation of government rations designated for aged and infirm Aborigines. Neville's response was to have them investigated by the very people who Piddington claimed were either involved or had previously ignored abuses. When Piddington's published allegations finally reached Neville, Neville claimed they were 'exaggerated' and 'misleading', and countered by accusing Piddington of drunkenness, singing the 'Internationale' and waving the Red Flag, abducting an Aboriginal woman, and removing Aboriginal men from a government reserve without permission. The ANRC Executive Committee was quick to support Neville..$^{2}$ They 'deplored' the action of Piddington:

The Executive Committee is in entire agreement with you [Neville] that any such statements that $\mathrm{Mr}$ Piddington desired to make public, should first have been submitted to your Department. The Executive considers that Mr Piddington's actions constitute a grave abuse of the hospitality extended to him in Western Australia. ${ }^{43}$

To Piddington they wrote that had they 'had those reports [from Neville] before it at the time you applied to the Rockefeller Foundation for your present fellowship 
[PhD], such support as the Council then gave your application would have been withheld.' '4 There was little attempt to investigate the 'truth' of Piddington's allegations. Rather there was an immediate reprimand, and the discussion focused on his behaviour rather than the substance of his criticism. Despite Piddington's clear statement that he had brought these matters to Neville's attention the ANRC assured Neville that there would not be a recurrence of such incidents.

Those researchers who could have supported his observations, such as A.P. Elkin and Gerhardt Laves, an American. linguist who had also worked at La Grange Bay, were used to undermine Piddington's credibility. 45 Elkin wrote to Ernest Mitchell, Chief Protector of Aborigines at La Grange, that he 'knew the situation in the west' but Piddington had 'pushed into the press with his criticism a little too soon, before having reported to the Research Council, and apparently before having satisfied the Western Australia authorities that he had consulted them.' 46 In the following year Alexander Gibson, honorary secretary of the ANRC, pointed out to the Rockefeller Foundation that Elkin had spent 'the greater part of two years in the North-West ... among ... the same people and the same type of people with whom so much friction has occurred in the case of [Piddington]', and that Laves had worked with Piddington. ${ }^{47}$ Neither supported Piddington's observations. Gibson acknowledged that Elkin, by then chair of the committee for anthropology, was 'not very favourable to including Piddington again in the team of anthropological workers. ${ }^{\prime}{ }^{8}$

The Rockefeller Foundation, on the other hand, took a different position. It recognized that those who 'would prefer charges' against Piddington 'would appear to be officials who might have been irked by Mr Piddington's criticism. Support for such a possibility would seem to be indicated by the length of time that intervened between Piddington's misconduct in Western Australia and the forwarding of charges to you [by Neville]'.49 On the same day the Rockefeller Foundation reassured Piddington that 'since your work ... has been satisfactory, your position with us is not altered by any information that we have received to date. '50 This contrasts with Donald Fisher's claim that the Rockefeller Foundation . exercised considerable control over British research institutions that it funded. ${ }^{51}$ In Australia the Rockefeller Foundation expressed no desire to dictate 'policy to the ANRC' and had no interest in Piddington's behaviour nor his political opinions..$^{2}$

Gibson wrote to Douglas Copland, Fellowship Adviser to the Rockefeller Foundation for the Social Sciences in Australia and New Zealand, that although the Rockefeller Foundation authorities 'would be glad if we employ' Piddington again, it 'would not be possible to send him to Western Australia' if he returned to 
Australia. ${ }^{33}$ Soon after, Copland informed Gibson that Piddington had been offered continued work in London 'devoting himself specifically to the study of African problems and languages in preparation for his field research Fellowship.'54 Gibson was relieved: 'the whole position has been one of great difficulty, and the problem will be more or less solved by the departure of Piddington for fresh fields, in a new continent.'55

Piddington, while he was not forced out of Australia, was because of his actions unable to find work at the University of Sydney which had the only Department of Anthropology in Australia. He completed his $\mathrm{PhD}$ and remained at the London School of Economics. In I938, he was appointed lecturer-in-charge in anthropology and keeper of the Anthropology Museum at the University of Aberdeen. He returned to Australia in 1944 to work with the Australian Army's Directorate of Research and Civil Affairs. In 1945 he was second-in-command to Colonel J.K Murray at the School of Civil Affairs, Duntroon (later the Australian School of Pacific Administration), which was responsible for training officers to work in the Australian territories of Papua and New Guinea. He returned to Britain in I 946 to take up the appointment of Reader in Social Anthropology in the University of Edinburgh. In 1949 he was appointed foundation Professor of Anthropology at the University of New Zealand (Auckland), a position he held until his retirement in $1972.3^{3^{6}}$

\section{AN 'UNDESIRABLE PERSON TO} ENTER THE BRITISH DOMINIONS'

Paul Kirchhoff studied Protestant theology and comparative religion at Berlin and Freiburg, and psychology and ethnology at Leipzig, where he developed an interest in the native cultures of the Americas. Until ${ }^{929}$ he served as a staff member of the Berlin Museum für Völkerkunde. ${ }^{57}$ He then worked under the linguist and ethnographer Edward Sapir at the University of Chicago between 1929 and $3^{0.5^{8}}$ At the end of $193^{I}$ he joined the International Institute of African Languages and Culture. From there he unsuccessfully applied for entry to South Africa to conduct research into 'social change and social stratification and its function.' 59 He was advised by Malinowski to apply for a Rockefeller Foundation fellowship from the ANRC.

Raymond Firth wrote to Malinowski that he was proposing Kirchhoff as a 'possible candidate for a research fellowship before the ANRC Anthropological Committee next meeting June zoth.' He advised Malinowski to get Kirchhoff to submit an application 'after the type of thing I sent a copy of to Camilla [Wedgwood]'. Firth thought there may be problems over Kirchhoff's '(alleged) Communism':

I'm not broadcasting it, but I can't keep entirely silent on his African episode. I have told [T.G.H.] Osborn [Professor of Botany, University of Sydney] ..., who is a decent person. It is important I think to have Kirchhoff backed in this case by English names. This is Osborn's suggestion ... but I 
imagine the effect [on] a righteous Godfearing British committee of the bundle of persons you cite behind a man whom the colonial office says is unacceptable-for Haddon or Marett or Elliot Smith...to write and say that he is a clean living person ... I can't leave the ANRC entirely in the dark ... I hope that this will suit the circumstances. Well backed by British of unquestioned purity. ${ }^{60}$

Kirchhoff wanted to research the effects of 'western influence on native civilization' in an ex-German colony, preferably in Japanese Micronesia, although the negotiations with the ANRC was with a view to Kirchhoff 'proceeding to an island [Nauru] in the Pacific under the administration of the Commonwealth of Australia.'6r

On September 2, 1932, the ANRC decided to offer him a fellowship and advised him by cable. Ten days later 'an officer called from the Commonwealth AttorneyGeneral's office, with a cable from the British Government' in which it was claimed Kirchhoff was a notorious communist' and an 'undesirable person to enter British dominions' who had already been refused entry to South Africa to do anthropological work. ${ }^{62}$ Soon after, the official provided them with a 'confidential document' which.showed Kirchhoff and his wife had used anthropology as a 'cloak for communistic activities in England'; in return Henry Chapman, treasurer of the ANRC, provided all the ANRC's files on Kirchhoff to the Attorney-General's office. ${ }^{6} 3$ The Australian government, acting on behalf of the British government, suggested that the ANRC 'might decide' to withdraw its offer to Kirchhoff to which Chapman and George Julius, president of the ANRC, acquiesced. Kirchhoff was notified that the offer was withdrawn. ${ }^{64}$

Julius and Chapman were subjected to considerable pressure by the Australian government: ' $\mathrm{A}]$ mess̀age has been received from Canberra urging that the ANRC make every effort to prevent the Australian Government being forced to exclude Dr Kirchhoff and his wife from Australia. ${ }^{6}{ }_{5}$ They explained to the Executive that 'an application has been made, or is again to be made by the German Government for the return of the Mandated Territory [New Guinea], and that it was not desirable that the British Government should bar Kirchhoff from coming to Australia', and the British Government 'would be just as embarrassed if Kirchhoff went back to Germany and said I am not to land in Australia.' ${ }^{66}$

To ensure that Kirchhoff did not attempt to enter Australia the ANRC cabled both Malinowski and Seligman seeking their assurances that he would not come. Sir David Orme Masson, ex-president of the ANRC and Malinowski's father-in-law, also wrote to him at the request of the $A N R C,{ }^{67}$ 'pointing out that the Kirchhoff matter was not to be given publicity' ${ }^{68}$ The ANRC insisted that Malinowski, Seligman, and Firth not divulge the reason for the 
withdrawal of their offer to Kirchhoff. Malinowski and Seligman agreed they would not tell Kirchhoff, and they assured the ANRC that he would 'waive any claim of a fellowship'. Masson was 'pretty sure our London friends and Kirchhoff himself will keep quiet about it', although the 'London' anthropologists were inclined to 'view leniently all sorts of erratic social and political theories'. 99

The Executive expressed their unhappiness with Firth for withholding information regarding Kirchhoff's barring from South Africa, and his 'communistic activities'. Julius stated that the ANRC 'should have been informed of all the facts of that kind. It puts us in a very difficult position'. It was further reported by Chapman that Firth considered 'an injustice had been done to Kirchhoff' but such sentiments had 'to go by the board when it is a question of embarrassing the British Government'. Firth, because he was 'not bound by any of the promises of confidence [Chapman] gave the AttorneyGeneral', was not told of the deliberations of the Executive. ${ }^{\circ}$

Malinowski, uneasy about the explanation from the ANRC, wondered if Firth knew the reasons, other than the potential embarrassment of the British government, why Kirchhoff was refused entry to Australia; in fact he 'would be grateful' if Firth devoted his 'energies to find out what the accusations against Kirchhoff have been and by what means they reached Australia. It would be extremely valuable in clearing up his character or else convicting him of his guilt in my eyes. ' ${ }^{11}$ Unfortunately Firth could not enlighten him.

Privately Seligman and Malinowski were concerned about Kirchhoff's treatment. Seligman, who had 'seen a good deal' of Kirchhoff, and from discussion with colleagues, concluded in a letter to Gibson that 'a number of us, including myself, ... are not prepared to accept as valid the reasons alleged for refusing him a visa for the African colonies'. $7^{2}$ Malinowski thought the 'whole affair' was a mistake either on the part of the 'secret police service or else some personal grudge of some important person'. He was 'absolutely convinced' that Kirchhoff was 'completely innocent' of anything but 'what he admits he has done, and that is nothing more than writing one or two articles to a perfectly open and official student paper and sympathising with the communistic cause in an amateurish, no doubt silly manner and that was years ago'. He thought most 'young people with spirit' have passed through a stage where they have seen themselves as 'revolutionaries or communists'. There was a distinction between this, which was 'completely innocent and irrelevant', and 'underhand plotting'. The persecution of people, like Kirchhoff, for 'silly or uncongenial opinions, openly published, by the weighty machine of secret service and punitive measures', was 'nothing short of criminal'. Nonetheless, if he suspected Kirchhoff of the 'underhand plotting' he 'would naturally wash my hands of him'. 
Malinowski was dissatisfied with the way the ANRC had behaved. Because of his close association with the Rockefeller Foundation he felt he could influence their decisions with regard to continued funding of the ANRC. He wrote to Firth,

I know that the Rockefeller Foundation are keenly interested in Kirchhoff. He has been now again granted a sum of money to study with me here to tide him over the next session and to allow him to publish some of his material collected in America. I certainly shall not shield the ANRC against the displeasure of the Rockefeller Foundation, if they have acted without due pressure from other quarters. For your Research Council living now on the Rockefeller Foundation, could have considered that this man was working for two years in the United States under direct supervision of Professor Edmond [sic] Day, now Director of the Social Science Department, Rockefeller Foundation. Since the Rockefeller Foundation exercises a very careful supervision of their students it is hardly likely that they should have for two years harboured a dangerous and criminal person, so dangerous and criminal that he cannot be sent on a coral atoll, inhabited perhaps by a few hundred Kanakas!73

There was no public protest from London and Kirchhoff, who faced the prospect of returning to Germany, stayed quiet. When his Rockefeller.Foundation fellowship ended Kirchhoff moved to Ireland; from there he wrote to Malinowski about the changing situation in Germany and how he could not envisage himself returning. ${ }^{74}$ He hoped for work in the United States probably at Harvard University. In this Malinowski encouraged him as he realize that Kirchhoff would no longer obtain work in Britain or its dominions and territories. ${ }^{75}$ In 1939 he was stripped of his German citizenship; he took out Mexican citizenship in r94. He was employed by the Museo Nacional de Antropologia, and

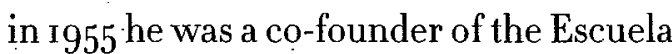
Nacional de Antropologia e Historia and at the same time held a professorial chair in the Universidad Nacional Autonoma de Mexico, a position he held until his retirement in $1965^{7^{6}}$

\section{III. 'A PERSON WHO MIGHT IMPEDE} OR DISTORT OUR WORK'

The Research School of Pacific Studies in the Australian National University (ANU) was to be a place of international standard research on the Pacific. Part of its charter was to attract and recruit postgraduate scholars from overseas. In r95 Peter Worsley, a returned serviceman and Cambridge graduate, was awarded a $\mathrm{PhD}$ scholarship in the ANU. His intention, supported by S.F. Nadel, Professor of Anthropology in the ANU, was to conduct fieldwork in the highlands of New Guinea. However, the university was informed that Worsley would not be granted a permit to enter PNG. His membership of the Communist Party was sufficient to make him a risk to the good order of the territory. Peter Worsley had earlier been banned from entering Britain's East African territories. It is likely this was unknown to the ANU at the time although 
it was most certainly conveyed to the Australian Security Intelligence Organisation (ASIO) by British intelligence. ${ }^{77}$

Peter Worsley arrived in Australia on 3 November 195. It was planned that Worsley and his wife would sail to New Guinea in June $195^{2}$. On May $5195^{2}$ the University forwarded to the Department of Territories individual applications to enter the joint Territory and on 26 May received a reply saying the issue of permits had not been approved. At the ANU's Council meeting of 27 June $195^{2}$ the ViceChancellor, Sir Douglas Copland, reported that Worsley had 'not been told the grounds on which the Minister's decision was taken officially but the Minister had granted the Vice-Chancellor a confidential interview.'The Minister authorized Copland to give this information to Worsley in confidence, which he did. Worsley, not satisfied, sought from Territories official confirmation of the reasons for refusal and was informed only that the decision had been made personally by the Minister, Paul Hasluck. He asked if Hasluck could inform him of 'the grounds upon which this decision was made'. Hasluck replied:

This decision was made in conformity with our established policy in regard to admission of Australians into the Territory and was only reached after full and careful consideration of the information placed before me. It is unlikely that the decision should be varied..$^{8}$
A month later the ANU Students'

Association wrote to the Minister:

The students of the Australian National

University condemn the unexplained action of the Minister ... in refusing permission to a student of anthropology of this university to proceed to New Guinea to undertake fieldwork essential for the completion of his $\mathrm{PhD}$ degree. It is the opinion of the student body that this action, so long as the Minister refuses to give reasons for it, constitutes an arbitrary interference with, and definite threat to academic freedom and liberty of enquiry, and cannot fail to have detrimental effect upon the work of the University.79

Hasluck replied that academic freedom had nothing to do with the case: he had 'exercised the powers and discharged the responsibility placed upon me in exactly the same way as I should have done in the case of an applicant from any other calling ... In case there is any misunderstanding I should like to add that the grounds for refusal ... had nothing to do with any question related to the applicant's personal character or personal habits. ${ }^{80}$ The Students' Association found Hasluck's reply unsatisfactory. They were dismayed that Hasluck acted on the basis of unspecified information withheld from public scrutiny: they urged the Minister to 'reveal the content and sources of his "information" ... in order to put an end to the growing fear in this University and elsewhere that both personal and academic freedom are under attack. ${ }^{.81}$

Concerned that it may have acted too hastily in accepting Hasluck's decision, the 
Council wanted to ensure that there was not a 'question of principle [academic freedom] involved' ${ }^{82}$ Copland assured them that there was not. But because the Students' Association had made the issue public Copland sought Council's support for the following statement:

It was true that a Scholar of the National University had been refused a permit to enter New Guinea ... It is understood that this refusal was on the grounds that would have applied to any citizen of Australia whatever his occupation or circumstances. As a member of the Australian community the Scholar was subject to the same administration and legal conditions as any other citizen. The fact that he was to pursue work in New Guinea as part of his course for a degree in the National University did not give him any standing other than the standing that any other citizen would have.

The Council approved of the ViceChancellor's statement. It was not considered that his membership of the communist party led to different treatment. The issue of academic freedom was elided:

It may be argued that this is an infringement of academic freedom. This argument cannot be sustained. A member of the University staff in respect of security regulations is in no different position to that of an ordinary citizen. $^{83}$

Hasluck, after questioning in Parliament, explained his decision:

[A] system requiring people to obtain permits ... has been in operation for more than twenty years. During that period ... two principles have been applied. First we have always tried to keep out of the territory ... persons who, because of lack of means or weakness of chàracter, might constitute in the territory something of the nature of a class of poor whites ... [T]he existence of such a class would be an embarrassment to us. Action in this case was not taken under that heading ... Secondly, we have always refused to admit certain people to the territory because we do not wish to have in the territory, persons who, by their activities, might impede or distort our work, or in other ways prevent Australia from discharging fully its responsibilities to the native peoples under trusteeship. The gentleman in question, by reason of his political affiliations, definitely comes within that class of person. All powers with any responsibility for the administration of dependent territories and colonial areas have realised in the last two or three years that a great deal of mischief can be done and much harm done to native peoples by persons holding certain views who go to such territories with the express purpose of trying to distort and misrepresent the work that is being done for the advancement of native peoples. In this case certain information was placed before me. In view of that I felt I was completely justified in refusing to issue a permit [to Worsley] in order to avoid the risk of damage being done to our work in New Guinea. In fact, I should have been lacking a sense of responsibility if I had issued a permit.

He added that the previous Labor Prime Minister, Ben Chifley, had set down a process for dealing with security matters, 'strictly adhered to constantly by this Government, [which] distinctly provides 
that the source of information in such matters shall not be discussed in public or made the subject of statements in this House.'

The ANU was keen to point out that it was not interested in the political affiliations of its staff nor had it been influenced by reports that have been received in a very few cases from official sources on the political views of applicants.' Although the government had 'not at any time sought to interfere in appointments, or to exercise control over the university' the University thought it unwise given the circumstances when so much attention is being given to so-called subversive activities, and when there is a certain amount of nervousness in the community ... to establish a special position for itself.' The University was prepared in matters to do with security to acquiesce to government requirements.

Much of the argument in support of the government's action to deny Worsley entry to Papua New Guinea was justified on two points. Firstly, that the government had the power to refuse entry, and secondly, that members of the University could not 'demand special privileges not accorded other citizens'. It was in this way that the University could situate Worsley's case as outside matters of academic (and civil) freedom. Initially it did not consider it to be an issue of academic let alone civil freedom despite statements by the Student's Association to the contrary. ${ }^{8 / 4}$ The Board of Graduate Studies, after discussion, had 'decided to ask Professor
Nadel to recommend to the Board plans for Worsley's future'; it was subsequently decided to seek permission for Worsley to carry out anthropological research at the Groote Eylandt Mission Reserve in the Northern Territory. Worsley was, after some delay, granted permission to enter the reserve. This, in part, reflects a differing perception of Aboriginal people in contrast to Papuans and New Guineans, international pressure, and a differing colonial enterprise. Nevertheless, Worsley, in 1992, stated that the intelligence services 'finally achieved their objective: forcing me out of anthropology. When I was told that I would never get an anthropological post, I decided I would have to turn to sociology. 85

Worsley was not the last ANU scholar to be refused entry, nor the only scholar concerned about past communist affiliations. Jeremy Beckett, for example, a scholar from University College, London, was likewise refused entry to PNG in the mid-fifties. ${ }^{86}$ Others, such as Oskar Spate, who was appointed to the chair in geography, was anxious lest his membership of the party when he was at Cambridge be used against him should he seek entry to PNG. It had already been used against him by Richard Casey who had blocked his projected appointment as First Commissioner of the South Pacific Commission. ${ }^{8} 7$ Hasluck assured Spate that he would not be refused entry, and in the same year that Worsley was refused entry, Spate was part of a group from the ANU that investigated economic and other 
matters associated with the territory. Max

Gluckman, a visiting professor of

anthropology at the ANU, was refused

entry in mid-r 960 because of his

communist party affiliations. ${ }^{88}$

\section{CONCLUSION}

The parallels between Kirchhoff and Worsley are many: British intelligence informing the Australian government agency, the sympathetic collaboration between the academy and the government, and the uncritical acceptance of what were allegations by a security organization ${ }^{89}$ In the case of Kirchhoff, the issue of national security was paramount in the eyes of the academic body. Where issues of security, or more precisely membership of the Communist Party, were alleged by a security service, the academic body elided the problem of academic freedom. The ANU finally recognized that their treatment of Worsley was an issue of academic freedom..$^{\circ} \mathrm{It}$ therefore addressed the problem of academic and civil freedom, but in the process it accepted without question information placed before it, albeit in an around-about way, by the ASIO which denied such freedoms.

Piddington's alleged communism did not cause the same concern with either the government or the security services. There seems little doubt that the Executive Committee of the ANRC was anti-communist which is reflected in Piddington's strenuous denial of any association with the Communist Party or communists. Raymond Firth wrote that Piddington was 'what was called rather "wild" at times. The "Red Flag"/

Internationale incident was such a wild prank. He and some friends got a bot [sic] drunk and wanted to annoy the good bourgeoisie: it was comic, not serious. Bu1 it marred the seriousness of his allegations. '91 Firth was well aware that Kirchhoff's communism was sufficient to cause problems with the Executive Committee and attempted to keep this knowledge from them.

Worsley, Kirchhoff, and Piddington reveal how a timid or politicized academic establishment acted in concert with a government instrumentality to stifle academic and civil freedom. The ANRC acted in concert with the government to stifle the civil rights of Kirchhoff, and in like manner it acted in concert with Neville to deny Piddington academic and civil freedom. In both instances they did not reflect on, nor interrogate, the evidence provided by the government authority; rather the information against both Kirchhoff and Piddington was uncritically accepted, and acted upon. In like manner the $\mathrm{ANU}$, largely because it was dependent upon the commonwealth government for funding, was reluctant to create a situation where it would publicly support Worsley.

In contrast to the intolerant and censorious nature of Australian academic culture was an international academic 
culture represented by the Rockefeller Foundation. It was tolerant of diversity, encouraged free and critical research, and was not concerned with personal behaviour and the self-interest of public servants. The Rockefeller Foundation showed that they were not concerned with the political affiliations or personal opinions of either Piddington or Kirchhoff. Both continued to be funded by the Rockefeller Foundation. Nevertheless, neither was able to work in Australia or its territories, while other anthropologists who remained silent continued to find employment and advancement in Australia.

Other scholars who were likewise subjected to scrutiny by the security service but did not make it public received support from the university..$^{2}$ Here the academy could work with the government in maintaining a fiction of academic freedom, and the government was saved the embarrassment of having to defend itself against charges of interference. ${ }^{93}$

The cases of Piddington and Pink, in particular, expose the ethical and political difficulties of working in the field. Pink found a solution by removing herself from the academy; Thomson, alone in Melbourne, continued his work outside mainstream anthropology (almost in defiance of Elkin and the Sydney department). Ronald and Catherine Berndt, while critical of Elkin's working behind the scenes, opted for a similar solution. They recognized that public silence enabled them to continue their research. The relationship between the academy and government was one of mostly sympathetic collaboration to silence public dissent that threatened the viability of a research program or of the institution itself.

\section{AFTERWORD}

The many, and at times, conflicting aims of anthropology-scientific knowledge, advancement, advocacy, institutional selfpreservation (to mention only a few) continue to beleaguer anthropologists to the present day.

The position of Aborigines being 'virtually inarticulate' has dramatically changed in the past three decades. ${ }^{94}$ The relationship between anthropologists and Aborigines has altered to such an extent that anthropologists require permission from Aboriginal organizations to conduct research. As well, as we have seen in Australia, anthropologists have difficulty positioning themselves in relation to Aboriginal people. This is particularly so over issues such as the Hindmarsh Island Bridge and 'secret women's business', which has highlighted the issue of advocacy as well as ethical and political difficulties. Anthropologists have been in sometimes heated disagreement over the authenticity of Ngarranjeri women's cultural practices and beliefs. ${ }^{95}$ Those anthropologists who found themselves in disagreement with the arguments accepted by the Royal Commission, ${ }^{96}$ have 
had their reputations, if not their careers, severely retarded. .97 Land rights, and recently Native Title, have become critical issues, and anthropologists now work for different interest groups..$^{8}$ Indigenous organizations employ anthropologists, as do mining and pastoral companies, and government. 99

It seems to me that on one level the critical questions for anthropologists now are for whom they work? and to whom they are ethically responsible? ${ }^{\text {?oo }}$ But this simplifies what are difficult questions. Nonetheless, if anthropologists accept as central that information obtained from indigenous peoples is not used in ways detrimental to the interests of those people, then the indigenous people with whom anthropologists work must have confidence in the commitment to this ethical tenet by anthropologists. ${ }^{\text {or }}$ Not all anthropologists think this consideration overrides what they see as public interest, and it is here that this paper has relevance. Thus what was for Ronald Berndt a simple issue of advocacy on the side of indigenous peoples is no more. Relations between anthropologists, Aborigines, and government are complex and difficult, and ethical and political considerations continue to be paramount. $\propto$

\section{GEOFFREY GRAY}

\section{Geoffrey Gray is a Research Fellow with the} Australian Institute of Aboriginal and Torres Strait Islander Studies.

\section{ACKNOWLEDGEMENTS}

I would like to thank Jeremy Beckett, Andrew Markus, Deborah Bird Rose, Christine Winter and an unknown referee for their comments at various times on aspects of this paper. Some of this paper was first presented as 'Academic freedom or security risk? surveillance, communists and the ANU', at the conference 'Espionage and CounterEspionage in Australian History. Left and Right in Australian Politics,' University of Western Sydney, Macarthur, II-I2 October 1996. Some of the research for this paper was assisted by a grant from the Centre for Citizenship and Human Rights, Deakin University.

\section{NOTES}

'Ronald M. Berndt, 'Practical Anthropology in Aboriginal Australia: some personal comments', Anthropological Forum, vol. 5 (2), I983-4, pp. I6r-175.

${ }^{2}$ J.A. Barnes, "Taking stock and looking forward', in R.M. Berndt and R. Tonkinson (eds), Social Anthropology and Australian Aboriginal Studies. a contemporary overview. Canberra: Aboriginal Studies Press. I 988. This view of Barnes is probably a bit harsh. For example C.D. Rowley, writing in I973, states that there were some notable exceptions with regard to public dissent, such as Stanner in I 964 who protested 'against the latest political moves to take from the northern Aborigines the few remaining rights they had to walk over, and use natural water in, the tribal country held under lease by pastoral companies'. Rowley, 'From Humbug to Politics: Aboriginal affairs and the Academy project'. Oceania, vol. 43 (3), 1973, p. 182.

3 There are some notable examples, not least Ron Crocombe of the ANU's New Guinea Research Unit, who was a critic in the 1960 s 
of embedded racism in Papua New Guinea.

Also Reo Fortune in Papua, I927-28.

4 See for example, Murray's letters to the

Minister with regard to Fortune and the practice of magic on Tewara, Papua. AA: $\mathrm{A}_{5}$ 8/1, A806/1/5.

5 For example, S.D. Porteus who conducted psychological investigation among Aborigines in north-west Western Australia guaranteed the government that any material they had filmed 'would [not] in any way reflect upon the handling of the natives' in that state. Porteus to Neville, zo November. Western Australia, State Archives of Western Australia, ACC 993, item I33/28.

${ }^{6}$ The argument that functionalism committed the anthropologist to a view which questioned any piecemeal civilizing of colonized peoples is unresolved in the Australian context. During Elkin's period as Professor of Anthropology (I934-1956) at the University of Sydney it is apparent that functionalism as practised by Malinowski and his disciples had short shrift in Australian Aboriginal anthropology. Elkin did not think Malinowski had much contribution to make to Australian Aboriginal anthropology. See Geoffrey Gray, "Mr Neville did all in [his] power to assist me": A.P. Elkin, A.O. Neville and anthropological research in northwest western Australia', Oceania, vol 68 (I), I997, p. 30 . Radcliffe-Brown believed that anthropological knowledge was beneficial to colonial administrators but his emphasis in applied anthropology was rarely argued in the Australian Aboriginal context. See also Cora Thomas, 'From "Australian Aborigines" to "White Australians": Elkin, Hasluck and the origins of assimilation', MA thesis, Monash University, 1994.

7 Fortune to J.H.P. Murray, 22 April I928. AA: $A_{5^{I}} 8 / 1, A 806 / 1 / 5$. See also Gray, "Being honest to my science": Reo Fortune and J.H.P. Murray, 1927-3o.'The Anthropological Journal of Australia (forthcoming).

${ }^{8}$ Ann McLean, 'In the Footprints of Reo Fortune', in Terence E. Hays (ed.),

Ethnographic Presents. Pioneering anthropologists in the Papua New Guinea highlands. Los Angeles: University of California Press. 1992, p. 5 I.

${ }^{9}$ See David McKnight, "The Australian Aborigines in Anthropology', in Richard Fardon (ed.), Localizing Strategies. Regional traditions of ethnographic writing,

Edinburgh: Scottish Academic Press, I99I, especially p. $5^{\circ}$.

ro For example Elkin's report to the Australian Board of Missions (ABM) on Ernest Gribble and his running of the Forrest River Mission. Elkin was so sensitive about this that he was anxious, some fifteen years after he made the report, that it be made public. ABM Papers, Mitchell Library.

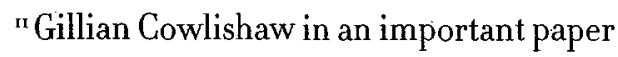
argued that Australian Aboriginal anthropology was based on notions of cultural and social authenticity and bloodthose Aborigines not of the 'full-blood' were of less interest culturally and socially, see G. Cowlishaw, 'Colour, Culture and the Aboriginalists', Man (NS), vol. 22, pp. 22I-237, I987. See also Julie Marcus, 'Racism, Terror and the Production of Australian Autobiographies', in Judith Okely and Helen Callaway, Anthropology and Autobiography, London: Routledge. I992. I would like to thank Deborah Rose for bringing this article to my attention.

${ }^{12}$ There is a present-day example of the close collaboration between anthropologists and government which is deserving of closer examination: the Hindmarsh Island Royal Commission and its aftermath. 
${ }^{13}$ Glen Alcalay, 'The United States

Anthropologist in Micronesia', in Lenora

Foerstel and Angela Gilliam (eds),

Confronting the Margaret Mead Legacy:

scholarship, empire and the south Pacific,

Philadelphia: Temple University Press. 1992, p. I86.

${ }^{14}$ Glenn Petersen, 'Politics in Post-War

Micronesia', unpublished paper (1993).

${ }^{15}$ Gerald D. Berreman, 'Is Anthropology Alive? social responsibility in social anthropology'; Gutorm Gjeesing, 'The Social Responsibility of the Social Scientist'; Kathleen Gough, 'New Proposals for Anthropologists', in Berreman \& Gjeesing, 'Social Responsibilities Symposium', Current Anthropology, vol. 9 (5), ig68, pp. 391-435; Talal Asad (ed.), Anthropology and the Colonial Encounter, London: Ithaca Press. I973. These debates led to the development of ethical guidelines for anthropologists in the USA and elsewhere, such as Australia. In $197^{\circ}$ it was revealed that the Defence Department, despite having abandoned Camelot in the late 1960 , had contracted a number of universities to collect intelligence in Northern Thailand in order to crush insurgent forces. Australia was involved in this through the Tribal Research Centre, established on the advice of W.R Geddes, then Professor of Anthropology at the University of Sydney. See L.R. Hiatt, 'Editorial', Mankind. vol 7 (r), rg69,pp. r-2.

${ }^{16}$ See for example, Gray, Mr Neville ...', pp. 27-46.

${ }^{17}$ Geoffrey Gray, "Piddington's indiscretion": Ralph Piddington, the Australian National Research Council and academic freedom', Oceania , vol. 64 (3), 1994. pp. 217-245.

${ }^{18} \mathrm{~A}$. P. Elkin, 'Anthropology in Australia: one chapter', Mankind, vol. 6 (6), I936, pp. 230-I.

${ }^{19}$ Elkin's emphasis. The diffusionists Elliot Smith and J.W. Perry, both of London University College, supervised Elkin's PhD thesis in $1926-27$.
${ }^{20}$ A.P. Elkin; 'The Journal Oceania': $193^{0-1970 . ~ a ~}$ history', Oceania Monographs no. I6, 1970, p. 12. See also D.J. Mulvaney, "Australasian Anthropology and ANZAAS": strictly scientific and critical', in Roy MacLeod (ed.), The Commonwealth of Science: ANZAAS and . the Scientific Enterprise in Australasia I888Ig88, Melbourne: Oxford University Press, 1988, p. 220. Nicolas Peterson notes that "although the letter of authorisation Elliot Smith carried with him from the Foundation ... was quite non-committal, the Foundation had already approved in principle a study in Australia on 27 February 1924 and recorded in its minutes that it awaited a mature definite proposal at a later meeting". Peterson, 'Studying Man and Man's Nature: the history of the institutionalisation of Aboriginal anthropology',Australian Aboriginal Studies, 2, 199o, p. Io. See also ANRC Papers, ANL, MS 482. Haddon also played a key role in the establishment of the chair of anthropology in Cape Town.

Raymond Firth, 'Alfred Reginald RadcliffeBrown i88I-1955', Proceedings of the British Academy, 42, 1956.

${ }^{21}$ Elliot Smith to Prime Minister, 2 September 1924. AA: $A_{5}$ 8, N8o6/1/r, Part I.

${ }^{22}$ Embree to Masson, 27 May 1926. I55/4/I/l, Elkin Papers (EP), University of Sydney Archives.

${ }^{23}$ The first committee consisted of RadcliffeBrown (Chairman), Masson (ANRC), A.H. Burkitt (Anatomy, University of Sydney), S. A. Smith (Physiology, University of Sydney), Frederick Wood Jones (University of Adelaide), Baldwin Spencer (University of Melbourne), and Nicholson (University of Queensland), J.G. McLaren (Commonwealth), Herbert Longman (Queensland), R.H. Pulleine (South Australia), T.T. Flynn (Tasmania), A.0. Nevịlle (Western Australia). Spencer also 
represented Victoria. In November 1927 the name was changed to the Committee on Anthropological Research and Fellowships in Anthropology and Biology.

${ }_{24}$ See Gray, Mr Neville ...',pp. 28-29. Also after Spencer's death the Professor of Anthropology was, until the appointment of Ian Hogbin in 1936, the only anthropologist on the committee.

${ }_{25}$ See ANRC Papers, ANL Ms 482.

${ }^{26}$ D.J. Mulvaney, 'Australian Anthropology since Darwin: models, foundations and funding', a paper presented to the Canada-Australia Workshop on Science and Technology, University of Victoria, British Columbia, 5-7 July r $99^{\circ}$.

${ }^{27}$ Kirchhoff is frequently misspelled as Kirchoff in the correspondence; I have decided to make the spelling of his name-Kirchhoffconsistent throughout the paper.

${ }^{28}$ Peterson, although sanitizing the language of the period, outlines the story in Donald Thomson in Arnhem Land compiled and introduced by Nicolas Peterson. Melbourne: Currey O'Neil. $198_{3}$ : See also $155 / 4 / 1 / 1$, EP for correspondence on Thomson's fieldwork in Cape York.

${ }^{29}$ Elkin set out the form the letter should take. See for example Elkin to G.S. Brown, nd; V.W. Coombes to Elkin, 14 January $1944 \cdot 76 / \mathrm{r} / \mathbf{1 2} /$ ${ }_{26} 6_{3}$, EP. Elkin was a member of the ABM Council, and the National Missionary Council.

$3^{\circ}$ For a fuller explanation see Ronald Berndt \& Catherine Berndt, End of an Era, I987, pp. xiv-xv; Geoffrey Gray, "It is not possible for conditions to remain as they are at present": The Berndts and the Australian Investment Agency survey, 1944-6', paper presented to Social Science Faculty, Deakin University. S.ptember 1992.
${ }^{3}$ Olive Pink, 'Camouflage', Mankind, vol. 2(I), $193^{6}$. This is an abstract of her paper. Its full text was never published.

${ }^{32}$ Julie Marcus, Yours Truby, Olive M. Pink, Canberra: Olive Pink Society. r99. p. I3

${ }_{33}$ Julie Marcus, 'The Beauty, Simplicity and Honour of Truth: Olive Pink in the I94os', in Julie Marcus (ed.), First in their Field. Women and Australian anthropology, Melbourne: Melbourne University Press. 1993. p.I23. In Elkin's Papers $(38 / \mathrm{I} / \mathrm{Io} / 3)$ there are numerous letters from Pink expressing her distrust and resentment of T.G.H. Strehlow and W.E.H. Stanner. Strehlow, son of the Lutheran missionary Carl Strehlow, was the acknowledged authority on the Aranda (among whom Pink first worked); Stanner had worked further north in the Daly River. region. Pink found both of them too complacent and compliant with government and those in authority.

34 It should be noted that Pink generally got on well with Elkin, although privately Elkin was critical of her. See correspondence in $3^{8 / \mathrm{I}} /$ Io/3, EP. For further discussion of Olive Pink, see Christine Cheater, 'Olive Pink and the "Native Problem"', Olive Pink Bulletin, vol. I (2), 1989:pp. 4-7; Julie Marcus, 'Olive Pink and the Encounter with the Academy', Mankind, vol. 17 (3), 1987. pp. 18 8-197; Gillian Cowlishaw, 'Olive Pink and the Hunter Gatherers', The Olive Pink Society Bulletin, vol. I ( I), I 989 . Pp. I/4-6. I draw heavily on their work.

${ }_{35}$ Firth had replaced A.R. Radcliffe-Brown in September 1932, who left Sydney to take up a position in the University of Chicago.

${ }^{36}$ Marcus, Yours Truly, p. 6.

${ }^{37}$ Marcus, Yours Truly, p. 8.

${ }^{38}$ Cheater, 'Olive Pink...' , p. 6.

${ }^{39}$ Elkin to Walkom, IoAugust ${ }_{93} 8.156 / 4 / \mathrm{I} / 14$, EP. 
$4^{\circ}$ Undated letter to her nieces, entitled 'My reasons for not publishing my research', quoted in Cheater, 'Olive Pink ...'.

${ }^{4}$ The World, 14 January $193^{2}$.

$4^{2}$ Alex Gibson, hon. secretary, ANRC, to A.O. Neville, 7 April 1933. ANL, Ms 482.

${ }^{43}$ Gibson to Neville, 2I October I932. ANL, Ms 482.

44 Gibson to Piddington, 23 December 1933. $\mathrm{ANL}, \mathrm{Ms} 482$.

45 Neville states in a memo to his Minister regarding Piddington's allegations that in Woodland's report there was a letter from Laves 'offering to support Spurling in the event of trouble following Piddington's eharges'. Memo, 25 August 1933. State Archive Western Australia, ACC 993, 133/30.

${ }^{46}$ Elkin to Ernest Mitchell, 5 October 1933.167 / $4^{/ 2} / 5^{\circ}, \mathrm{EP}$.

47 Gibson to Stacy May (Rockefeller Foundation), 4 July I934, ANL, Ms 482.

$4^{8}$ Gibson to Elkin, 6 September I934. I56/4/I/12, EP.

49 May to Gibson, 30 April 1934. ANL, Ms 482.

$5^{\circ}$ May to Piddington, $3^{\circ}$. April 1934. ANL, Ms 482.

${ }^{5}$ Donald Fisher, American Philanthropy and the Social Sciences in Britain, I9rg-r939: the reproduction of a conservative ideology', The Sociological Review (NS), vol 28 (I), 1980, pp. $277-315$.

$5^{2}$ May to Gibson, 30 April i934. ANL, Ms 482.

53 Gibson to Copland, 2 October I934. Ms 482.

${ }_{54}$ Copland to Gibson, 19 November 1934 . Ms 482 .

${ }_{55}$ Gibson to Copland, 1o December I934. Ms 482 .

${ }^{6}$ Bruce Biggs, Obituary, Proceedings of the Royal Society of New Zealand, vol. 103, p.127.
57 Frauke Johanna Riese, in Christopher Winters (ed.), International Dictionary of Anthropologists, New York: Garland, 199r, pp. $34^{8-9}$.

${ }^{8}$ Regna Darnell, Edward Sapir: linguist, anthropologist, humanist, Berkeley: University of California Press. I99o,p. 208.

${ }^{59} \mathrm{Kirch}$ off's research proposal, ANL, Ms 482.

${ }^{60}$ Firth to Malinowski, I June ig32. Bronislaw Malinowski Papers, Correspondence $1869-$ (I914-I939). Ms. GR. No. Ig, Series I. Firth expected to take up a position as lecturer at the London School of Economics in September 1932.

${ }^{61}$ Presumably a copy of the 'confidential document'. ANL, Ms 482. This document carries a date of In August 1932. It would seem that the British informed the Australian government when they heard that Kirchhoff was applying for anthropological work with 'an anthropological group'. It was not, however, until Kirchhoff made a formal application that this information was used.

${ }^{62}$ The British government didn't deport him 'on the understanding that anthropological work would be found for him outside the British Empire'. Frank Cain, The Origins of Political Surveillance in Australia, I983. p. 241 .

${ }_{3}^{6}$ Copy of Attorney-General's statement, Ms 482.

${ }_{64}$ Chapman to Masson, ${ }_{3} 3$ September $193^{2}$. Ms 482 .

${ }_{55}$ Chapman to Masson, 23 September 1932. ANL, Ms 482 .

${ }^{66}$ Minutes, Executive Committee, ANRC. Ms 482 .

${ }^{6}$ Masson to Chapman, 3 October; Chapman to Masson, 8 October 1932. r932. ANL, Ms 482.

${ }^{68}$ Masson to Chapman, 16 October I932. ANL, Ms 482 .

69 Masson to Chapman, I6 October I932. He also added that he personally disliked 'most of the 
-isms and [I] rather think tolerance can be carried too far-and has in the past.'

$7^{\circ}$ Minutes, Executive Committee, ANRC. Ms $4^{82}$. One member, G.A. Waterhouse, stated that 'the sooner we get rid of him [Firth] the better.' Raymond Firth states that Chapman 'came to see me [and] made it quite clear that the British government had made the request to the Australian government that K's grant be disallowed, and that the ANRC would feel bound to comply with the Australian government wish to accede to the request. About why this request had been made we were then not clear, but later the allegation of communism emerged'. Firth to author, ${ }_{5}$ April 1998 .

${ }^{71}$ Malinowski to Firth, 29 September $193^{2 .}$ Malinowski Papers.

$7^{2}$ Seligman to Gibson, 27 September 1932. ANL, Ms 482 .

${ }_{73}$ Malinowski to Firth, 29 September I932. Malinowski. Papers.

74 Kirchhoff to Malinowski, 3 March I933; 25 January, r934. Malinowski Papers. I would like to thank Professor Walter Veit, German Studies, Monash University, for translating the relevant sections of these letters.

${ }^{75}$ Malinowski to Kirchhoff, 30 January I934. Malinowski Papers.

${ }^{76}$ Riese, in International Dictionary of Anthropologists, pp. 348-9.

${ }_{77}$ See Frank Cain, The Origins of Political Surveillance, for a discussion of the relationship between British and Australian Security in the interwar years.

${ }^{78}$ Hasluck to Worsley, 13 June $195^{2}$. ANU file .6.4.1.49. It is interesting to note that in $A$ Time for Building. Australian administration in Papua and New Guinea, $195^{I-1963 .}$

Melbourne: Melbourne University Press (1976), he makes no mention of Worsley or the issues of entry for those suspected of political subversion, other than Max Gluckman and the use of ASIO in the territory from c. 1960 .

${ }^{79}$ ANU file, 6.4.I.49

${ }^{80}$ Hasluck to ANU Students' Association, 8 July 1952. ANU file 6.4.I.49.

${ }^{8}$ ANU Students' Association to Hasluck, I4 July 1952; Hasluck to ANU Students' Association, 24. July.1952. ANU file, 6.4.1.49.

${ }^{82}$ From Minutes of Council, 27 June r952. ANU file 6.4.I.49

$8_{3}$ See Council Memo, 'Note on Academic Freedom'. ANU file 6.4.r.49.

84The Students' Association urged the Minister to reveal the content and sources of his "information" ... in order to put an end to the growing fear in this University and elsewhere that both personal and academic freedom are under attack.' ANU Students' Association to Hasluck, 14 July $195^{2}$. ANU file 6.4.1.49.

${ }^{8}$ Peter. Worsley, 'Foreword', Foerstal and Gilliam, Confronting the Margaret Mead Legacy, p. ix.

${ }^{86}$ Jeremy Beckett, 'Against the Grain: unreliable recollections of anthropology in Australia', in Geoffrey Gray (ed.), Reflections on Australian Anthropology (forthcoming I998).

${ }_{7}^{8}$ S.G. Foster and Margaret M. Varghese, The Making of the Australian National University, Sydney: Allen \& Unwin, r996, p. r22. Stanner was proposed as Spate's replacement but was first investigated by Richard Casey: '[I] am having him checked out first by Spry [ASIO]'. Casey to Copland, ir September 1952. Quoted in Foster and Varghese, p. $43^{\circ}$.

${ }^{88}$ Hasluck, $A$ Time for Building, pp. 403-405.

${ }^{8}$ See David McKnight,Australia's Spies and their Secrets, Sydney: Allen \& Unwin, 1992 Frank Cain, The Australian Security Intelligence Organisation: an unofficial 
history. Richmond: Spectrum Publications. I994.

$9^{\circ}$ See Foster and Varghese, The Making of the $A N U$, pp. II3-12 6 for a discussion the ANU and academic freedom.

${ }_{91}^{9}$ Firth to the author, 20 February 1993.

${ }^{92}$ Foster and Varghese, The Making of the $A N U$, pp. 120-126.

${ }^{93}$ See Foster and Varghese, The Making of the $A N U$, pp. rrz-126 for discussion of these matters.

${ }^{44}$ See Barnes, 'Taking stock ....

${ }_{95}$ See for example, Lyndall Ryan (ed.), Secret

Women's Business: the Hindmarsh Island

affair, special issue Journal of Australian Studies, no. 48, 1996; Phillip Clarke,

'Response to "Secret Women's Business": The Hindmarsh Island Affair', Journal of Australian Studies, no. 50/5I, 1996, pp. 141149; Ron Brunton, Blocking Business. an anthropological assessment of the Hindmarsh Island dispute, Tasman Institute Occasional Paper B31, I995; The False Culture Syndrome. The Howard Government and the Commonwealth Hindmarsh Inquiry, Institute for Public Affairs Backgrounder, vol. 8 (2), I996; Robert Tonkinson, 'Anthropology and Aboriginal Tradition: the Hindmarsh Island bridge affair and the politics of interpretation', Oceania, vol. 68 (I), 1997, pp. I-26.

${ }^{96}$ Iris E. Stevens, Report of the Hindmarsh Island Bridge Royal Commission. Adelaide: State Print. 1995.

${ }^{97} \mathrm{An}$ academic journal, so I have been informed, rejected a paper on Hindmarsh because of its anxiety about objectivity.

${ }^{98}$ See Deborah Bird Rose, 'Anthropological. ethics for the native title era', in Jim Fingleton and Julie Finlayson (eds), Anthropology in the Native Title Era. Proceedings of a workshop.
Canberra: Australian Institute of Aboriginal and Torres Strait Islander Studies. 1995. Here is outlined a range of ethical issues facing anthropologists working in Native Title.

${ }^{99}$ The recent Yorta Yorta/Bangerang Native Title case is an example. Rod Hagen and Deborah Bird Rose were expert witnesses for the Yorta Yorta/Bangerang, and Ron Brunton and Ken Maddock were expert witnesses for those opposing the Yorta Yorta/Bangerang claim.

${ }^{100}$ American anthropologists, for example, developed a code of ethics in $197 \mathrm{r}$; it was nearly the end of the decade when Australian anthropologists developed a similar code. These offer a guide to anthropologists.

${ }^{100}$ The Australian Anthropological Society Code of Ethics (n.d.) states, inter alia, 'Members should not knowingly or avoidably allow information gained on a basis of trust and cooperation of those studied to be used against their legitimate interests by hostile third parties'.

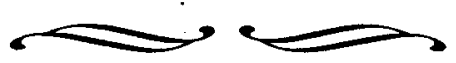

